Volume 1 Issue 2, September 2016: pp. 234-246. Copyright @ LamLaj. Faculty of Law, Lambung Mangkurat University, Banjarmasin, South Kalimantan, Indonesia. ISSN: 2502-3136 | e-ISSN: 2502-3128. Open Access at: http://lamlaj.unlam.ac.id

\title{
The Settlement of Disputes Between The Workers and Wetland Palm Oil Company in the District of Barito Kuala
}

\author{
Yulia Qamariyanti' ${ }^{1}$, Ahmad Syaufi ${ }^{2}$, Diana Rahmawati ${ }^{3}$, Rahmat Budiman ${ }^{4}$ Saprudin $^{5}$ \\ ${ }^{1}$ Faculty Of Law, Lambung Mangkurat University \\ Jalan Brigjend H Hasan Basry Banjarmasin 70123 \\ Telp/Fax: +62 (511) 3307877 E-mail: yuliaqamariyanti@yahoo.com \\ ${ }^{2}$ Faculty Of Law, Lambung Mangkurat University \\ Jalan Brigjend H Hasan Basry Banjarmasin 70123 \\ Telp/Fax: +62 (511) 3307877 E-mail: asyaufi@yahoo.co.id \\ ${ }^{3}$ Faculty Of Law, Lambung Mangkurat University \\ Jalan Brigjend H Hasan Basry Banjarmasin 70123 \\ Telp/Fax: +62 (511) 3307877 E-mail dianaunlam@gmail.com \\ ${ }^{4}$ Faculty Of Law, Lambung Mangkurat University \\ Jalan Brigjend H Hasan Basry Banjarmasin 70123 \\ Telp/Fax: +62 (511) 3307877 E-mail: rahmat7346@gmail.com \\ ${ }^{5}$ Faculty Of Law, Lambung Mangkurat University \\ JalanBrigjend H Hasan Basry Banjarmasin 70123 \\ Telp/Fax: +62 (511) 3307877 E-mail : saprudin.fhunlam@gmail.com
}

Diterima: 25/07/2016; Revisi: 18/09/2016; Disetujui: 30/09/2016

\begin{abstract}
Barito Kuala District has developedpalm oil plantation sector in wetlands area which gradually changed the pattern of its community life. Previously, most of the people were sharecroppers with the land as their main commodities, then they become the labor because the companies employ people especially from the local community. This research is an empirical legal study to obtain primary data and literature study to obtain secondary data. Its population is the palm oil plantations in Barito Kuala District and the sample is palm oil plantations in wetlands, which employ workers. In relation to the employment, there are sometimes disagreements among the parties which can be caused by a variety of factors. The settlement of the industrial disputes is through stages of the bipartite; the mediation (tripartite); conciliation; arbitration; and the Industrial Relations Court. Industrial Relations Court is the last effort for the disputing parties in industrial relations that can not be resolved through out courts, regulated in Law Number 2 of 2004 concerning Industrial Relations Court.
\end{abstract}


Key Words: dispute solution, workers and employers, oil palm plantations

\section{INTRODUCTION}

Manpower development as an integral part of national development based on Pancasila and the Constitution of 1945 is carried out for and in order to complete Indonesian human development and the development of Indonesian society. In a more specific meaning, it is to enhance the dignity and the worth of the workers to achieve the equitable welfare, justice, prosperity, both materially and spiritually.Thecapabilities in the field of science and technology as well as new era development and market opportunities domestically and abroad by improving the quality of human resources in Indonesia in general and the role of workers in the implementation of national development in particular, both as the agents of development as well as the development goals. ${ }^{1}$

For development goals, workers need to be protected in all aspects, including the protection in finding work within the country and abroad. Protection of the fundamental rights of workers, protection of health and safety and protection of wages and social security so as to guarantee security and peace as well as the fulfillment of justice and the realization of a prosperous life physically and spiritually, harmonious-sly and in balance. Manpower development has many dimensions and linkages not only with the interests of workers before, during and after employment but also related to the interests of employers thoroughly and comprehenddsively in order to raise the performance of workers to improve the

1 Suhariwanto, Aspek Hukum Perlindungan Pekerja Dalam Mengantisipasi Pemogokan Kerja di Perusahaan. Unitas Vol.9 No. 1, September 2000-Pebruari 2001, hlm. 72-73. productivity and competitiveness of Indonesian workers, human resource development as well as to increase aworkerprotection. ${ }^{2}$

Labor has always been a weak party when facing the employer who is a party that has the power; as a party that has always been considered weak, it is not uncommon that workers always suffer injustice when dealing with the interests of the company. Therefore, the Labour/Employment Law aims to protect the interests of workers / employees, it is based on a philosophical basis that labor is always the subordination of entrepreneurs; therefore, the law is set up to neutralize the imbalances. Thus when a law is not able to balance this subordinate, it might happen because of a failure in the substance and interest in the field which is more aligned to employers rather than the workers. ${ }^{3}$

The researcher would like to investigate more about how the settlement of disputes between the workers and the wetland palm oilin Barito KualaDistrict.

\section{METHOD}

This research is an empirical legal research that focuses on the field researchto obtain primary data and a library research to complement and support the data obtained in the field. This library research uses secondary data which is derived from the three ingredients of the law namely the primary legal materials, secondary law and tertiary legal materials.

The types of data collected is secondary data as well as the normative legal research;

\footnotetext{
2 Ibid.

3 Adrian Sutedi,2009, Hukum Perburuhan. Jakarta: Sinar Grafika, hlm. 57.
} 
therefore, the study of documents is used as a means of data collection. ${ }^{4}$

Data collection instruments consist of various types. For Library Research, the instrument used is the document studies on three kinds of legal material namely the primary legal materials, secondary law and tertiary legal materials; and for Field Research, the methods are interview and questionaire. Guided interview is used to obtain data from some sources, the informants and the respondents.

Thepopulation of the respondents are the workers at wetland palm oil companies in the District of Barito Kuala and the selection of the respondent samples was conducted on the companies selected by the researchers. The sampling technique is by applying non probability sampling which was done nonrandomizedly. The researchers use purposive or judgmental sampling which is to use the researchers' judgment and knowledge about the population in selecting the samples. The data obtained mostly directs to the conclusion drawing, but it generally can not be used as the basis for statistical testing. ${ }^{5}$ In addition to the respondents, those who became the informants and source persons are people from the Government either from Statistics Central Bureau of South Kalimantan Province, Central Statistics Agency of Barito Kuala District, the District Office of Manpower and Transmigration of South Kalimantan Province, the District Office of Social, Manpower and Transmigration of Barito Kuala District and palm oil plantation companies in Barito Kuala District, the Industrial Relations Court

4 Maria SW Soemardjono, 1989, Pedoman Pembuatan Usulan Penelitian, Yogyakarta: Fakultas Hukum Universitas Gadjah Mada, hlm. 23.

$5 \quad$ Ibid, hlm. 20. based in Banjarmasin District Court, and the parties associated with the settlement of labor disputes in Barito Kuala

\section{RESULTS}

Industrial Relations is a legal relationship based on agreement between the parties which bind themselves in a work relationship between the employer and workers. Sometimes the relationshipmight end up in a dispute. Disputes in the field of industrial relations can occur due the rights that have been set, or due to the state of employent that has not been established, even in the employment contracts, company regulations, collective labor agreements and legislation, and also the termination of employment. If one party no longer wishes to be bound by the employment relationship, it is difficult for the related parties to maintain a harmonious relationship. ${ }^{6}$

In the field of employment, disputes between employers and workers usually originate fromtheunsatisfied feelings. Employers issue policies which they consider good and will be accepted by the workers; however, the workers have different views. Workers who are satisfied will still work even more excitedly, while workers who are not satisfied will show a decrease in the work spirit and lead to the potential occurrence of disputes between workers and employers. ${ }^{7}$

Law No. 2 of 2004 on the Settlement of Industrial Disputes (here in after referred to as PPHI Law) mentions that the Industrial Dispute is a difference of opinion resulted in a

6 Saprudin, 2013, Perkembangan Hukum Ketenagakerjaan di Indonesia, Yogjakarta: Aura Pustaka, hlm. 115.

7 Zaeni Asyhadie, 2007, Hukum Kerja Hukum Ketenagakerjaan Bidang Hubungan Kerja, Jakarta: PT.Raja Grafindo Persada, hlm. 127. 
conflict between employers or joint employers and workers / laborers or union / labor unions for their disputes are regarding the rights, interestsdisputes, terminate on of employment disputes and disputes between trade unions / labor unions in a company. On that basis, the PPHI Law divides the industrial relation disputes into: ${ }^{8}$

1. Disputes of rights;

2. Disputes of interests;

3. The disputes in the termination of employment;

4. The dispute between trade unions / labor unions within a company

Toward the disputes that occur, the best solution is needed for both parties to determine the forms of the settlement so that the Industrial Relations Court as stipulated in PPHI Law is able to resolve the cases of employmenttermination that is not accepted by one of the parties.

In line with the era of directness and democratization in the industrial world, it is realized by the freedom to associate for the workers that resulted in the number of unions in one company whichcan not be restricted. Competition between unions in a company can result in dismissals among unions, which generally deals with issues of membership and representation in negotiations of the collective labor agreement.

The best dispute solution is thesettlement by the disputantsto obtain results that benefit both parties. For example, the bipartite settlement can be done through consensus by the parties without interference from any party. In an effort to provide public services, especially on the workers and the

$8 \quad$ Ibid, hlm. 117. employers, government is obliged to facilitate the settlement of the industrial disputes. The effort of facilitating is by providing a mediator assigned to reconcile the interests of both parties on the dispute.

Based on Article 1 paragraph ( 1) of the PPHI Law, what is meant by an industrial dispute is a "difference of opinion resulted in a conflict between employers or joint employers with workers or unions for their disputes are regarding rights, conflicting interests, a dispute over termination of employyment, and disputes between unions within a company. Based on such understanding, then the type of industrial disputescan be categorized as:

1. The disputes of rights; disputes arising due to nonfulfillment of rights, as an effect of differences in the application and interpretation toward the provisions of legislation, work agreements, company regulationns or collective agreements;

2. The disputes of interest; disputes that arise in the employment relationship because of the lack of conformity on opinion regarding theestablishent and / or changes in the terms of employment stipulated in the employment agreement, and company regulations, or collective agreements;

3. The disputes in the termination of employment; disputes arising from the absence of opinion regarding the appropriateness of termination by either party;

4. The dispute between trade unions / labor unions within a company; disputes between the unions / labor unions which are in one company due to the lack of understanding regarding the conformity of the membership, the implementation 
of the rights and obligations of union membership.

Based on the material scope of the industrial disputes as mentioned above, the explanation of PPHI Law is further elaborated that the industrial dispute is basically regulated as follows :

1. The solutionisarranged forthe industrial disputes that occur both in private companies or companies under the BUMN;

2. The litigants are individuals and organizations of workers unions, or between the unions and withina company;

3. Each of industrial disputes was originally settled by deliberately by the disputing parties (bipartite);

4. In the case of failed bipartite negotiations, then one party or both parties recorded their disputein the government agency responsible for manpower affairs;

5. Interest disputes, disputes in the termination of employment or disputes between unions that have been recorded at the agency responsible for labor affairs can be settled through counciliation on the agreement of both parties, while the settlement of disputes through arbitration on the agreement of both sides is only on interest disputes and disputes between labor unions. If there is no agreement by both parties to resolve the dispute through conciliation or arbitration, then before it is submitted to the Industrial Relations Court, it should firstly be through mediation. This intends to avoid the pile of industrial dispute cases in the courts;

6. Disputes of rights which have been recorded at the agency that responsible for labor affairs can not be settled through conciliation or arbitration, but before it is submitted to the Industrial Relations Court, itshouldfirst be through mediation;

7. In the case of mediation or conciliation which cannot reach an agreement was set in the collective agreement, then either party may submit a claim to the Industrial Relations Court;

8. The settlement of industrial disputes through arbitration is done by agreement between the parties and can not be submitted as a claim to the Industrial Relations Court for arbitration decision is permanent and final, except in certain cases which annulment to the Supreme Court can be filed;

9. Industrial Relations Court exist in the General Courts and it'sformed in the District Court gradually and at the Supreme Court;

10. To ensure a quick, accurate, fair, and lowcost settlement, the solution of industrial relationns through the Industrial Relations Court in the General Jurisdiction is limited in the process and stages by not providing an opportunity appeal to the High Court. The decision of the Industrial Relations Court on the rights disputes and the disputes in the termination of employment can be directly requested to the Supreme Court;

11. Industrial Relations Court that examines and adjudicates the industrial relations disputes is by a panel of judges consisting of three judges, namely a District Court judge and two ad hocjudges whose appointments are proposed by the organizations of employers and workers.

The industrial relation disputes can generally be settled the stages as follows:

\section{Bipartite}


Before the dispute is brought to the dispute settlement institution, any dispute shall be pursued in a bipartite settlement, namely discussion between workers and employers. Based on the PPHI Law Article 1 point (10), bipartite negotiations are dialogs between workers or unions and employers to resolve an industrial relation dispute.

Any industrial relation dispute settlement shall be pursued first through bipartite negotiations to reach consensus. Bipartite settlement of disputes should be resolved no later than 30 (thirty) business days from the date of negotiations. If within that period,either party refuses to negotiate or the negotiations have reached an agreement, then the bipartite negotiations are considered failed.

If the bipartite negotiations fail, then one or both parties must record their dispute to the agency which is responsible for local manpower to attach evidence that remedies bipartite negotiations have been conducted. If the evidence it is not attached, the government agency is responsible for returning the documents to be completed no later than seven working days from the date of the returned file. After receiving a report from one party, local employment office is required to offering the parties to agree to select a settlement through conciliation or arbitration.

\section{Mediation (Tripartite)}

Tripartite is stipulated in Article 8 to Article 16 of PPHI Law. Dispute settlement through mediation is conducted by mediators who are assigned in every local Manpower office. At the latest time of seven working days after receiving the delegation of dispute settlement, the mediators should have conducted an investigation regarding the case and immediately held a mediation session. The mediator may summon witnesses or expert witnesses to attend the mediation hearing to be questioned.

In the case of agreement settling the industrial relation disputes through tripartite, then a collective agreementis signed by the parties and witnesssed by the mediators, and it isregistered in the Industrial Relations Court to obtain a registration deed. If no settlementagreement is reachedthroughamediation, then:

1. The mediator issued a written recommendation;

2. The written recommendation is submitted no later than 10 (ten) days;

3. The parties should have given a written answer to the mediator whether to approve or reject the recommendation from the mediator;

4. Thearties that do not provide an answer is considered rejecting the recommendation from the mediator;

5. If the parties accept the recommendation from the mediator, a written report shall immediately be made and registered to the local Industrial Relations Court.

Mediation agency is basically almost the same with the institution mediator that is provided by employees of the Labor Department as it has been known. Officers who conduct themediation are mediators who are the employees of the Department of Labor that will provide a written recommenddation to the parties which have a dispute.

The difference is that previously each dispute is obliged to go through the mediation process first, then based on the PPHI Law, the Department of Labor first offered to the parties to choose conciliation or arbitration. If the parties within seven working days do not provide answers to the settlement of disputes, 
it will be referred to the mediator. As to rights disputes, after receiving the results of the bipartitenote, the Department of Labor shall forward the settlement of disputes to a mediator. This is because the Industrial Relations Court may only accept cases concerning industrial relations rights disputes that have gone through the mediation process

\section{Conciliation}

Dispute settlement institutions are authorized to mediate in the interest disputes, the disputes in the Employment Termination (PHK), and disputes between unions, who served as a conciliator that is qualified based on the Minister's decision and shall provide a written recommendation to the parties that are in dispute. If the conciliation process does not reach an agreement, then either party may file a lawsuit against the Industrial Relations Court

\section{Arbitration}

Institutions which are authorized to be a referee in the the interest disputes and disputes between unions, are served as the referees is socalled arbitrators. The arbitratorsareselected by the parties which are in dispute from the list appointed by the Minister. According to Article 1 Paragraph 5 of PPHI Law, arbitration in industrial relations is the settlement of an interestdispute, and the disputes between trade unions within one company outside the Industrial Relations Court through a written agreement of the disputants to submit the settlement of the dispute to the arbitrator whose decision binding on the parties and is final

The settlement of industrial di-sputes through arbitrators is on the basis of agreement between the disputing parties. The agreement of the parties that are in dispute are set forth in the letter of the arbitration agreement, made in triplicate and each party has got one that has the same legal force and includes:

a. The identities of the disputing parties;

b. The subject that became an industrial relation dispute to be settled through arbitration;

c. The number of arbitratorsagre-ed;

d. Statement by the disputing parties to submit and execute the arbitration decision;

e. The place and date of the agreement and signature of the disputing parties.

In the trial of arbitration, the disputing parties may be represented by legal counsel. If on the day of the hearing, all parties without a valid reason are not present, then the arbitrator or panel of arbitrators may cancel the appointment of arbitrators and the arbitrators considered the task is comp-leted. If on the day of the first session and the next session, one of the parties is not present for no apparent reason, then the arbitrator can hear cases and impose its decision without the pres-ence of one of these parties.

The settlement of industrial relationdisputes by the arbitrator shall be preceded by efforts to reconcile the two disputing parties. If reconciliation is achieved, then the arbitrator shall make the settlement deed signed by the parties and arbitrators. This deed is then registered in the Industrial Relations Court. On the other hand, if the reconcialiation fails, the arbitrator will continue the arbitral trial.For the activities of the arbitral trial, an investigation report is made by the arbitrator. The arbitration decision shall contain:

a. Head of the decision which reads "For the sake of justice by Almighty God";

b. The identity of the arbitrator; 
c. The identities of the parties

d. The things contained in the agreement proposed by thepartiesin dispute;

e. Overview and demands, answers, and explanations of the parties;

f. Consideration of the legal basis;

g. Principal decision;

h. The place and date of the decision;

i. The entry when the decision is into force;

j. ArbitratorSignature.

\section{Industrial Relations Court}

Industrial Relations Court is the last effort for the disputing parties in industrial relations dispute. These parties must first go throughthebipartite settlement, mediation, or conciliation; however, those efforts do not result in an agreement. So the Industrial Re-lations Court is the final stage for the settlement of disputes that can not be resolved out of the court. For arbitration, a legal effort cannot be requested to the Industrial Relations Court for a decision from the arbitration a have binding legal force as well as court sentences.

Of some alternative dispute settlements, then the best solution for the disputes in the employment relationship is through the settlement out of co-urt or non litigationnamely bipartite, mediation, conciliation, and arbitration. This is because there are several adventagesshown by the path of non litigation including the divergencecompletion pattern which simpler than the path of litigation, the freedom of the parties to appoint a mediator in the dispute settlement process, the emphasis on the principle of consensus, and also therelatively shorter and low cost way than the litigation path. Besides, the deci-sionmight also bring a legal effect in the path of non-litigation which also led to the selection of nonlitigation lines preferred. The position of settlement through litigation will only be reached when the non-litigation settlementcannot be achieved.

In line with the era of globalization, of course, the demands of the labor dispute settlement also requires an umbrella in a variety of legislation products which could anticipate them. Prior to the reforms in the law labor and employment issues, labor dispute settlementis still regulated by the previous law, among others:

1. Law No. 22 of 1957 on the Settlement of Labor Disputes (State Gazette No. 42 of 1957)

2. Law Number 12 Year 1964 con-cerning the Termination of Employment in Private Companies (State Gazette No. 93 of 1964).

These two products of legislation makethe labor dispute resolution more focused on consensus between the workers and the employers through the Institute of Bipartie, and if the dispute is unresolved, it may be preceded to Tripartie Institute, and so on can be continued to the Court of P4D and P4P.

However, nowadays whenlabor issues become more and more comp-lex, the previous legislation can no lon-ger give a solution to the labor dispute, so other laws such as the Law on Human Rights No. 39 of 1999, Law on Unions No. 21 of 2000 and Law No. 2 of 2004 on the Settlement of Industrial Disputes are enacted.

\section{Labor Dispute Settlement through the National Commission on Human Rights}

Law No. 39 of 1999 on Human Rights provides an opportunity for Labour and Employment in resolving labor disputes. Although many people do not understand about the procedure of dispute settlementonLabour through the National Commission on Human Rights, Law No. 39 of 1999 provides an 
opportunity that labor dispute can be resolved through the Human Rights National Commission. In Article 89 Pa-ragraph 3 Sub $\mathrm{h}$, it is stated that the National Commission on Human Righys can resolve and give an opinion on the public disputes, either on worker cases that were brought or has not been brought to trial. The explanation of the Act states that public disputes referred to in the Act on Human Rights include three classes of outstanding disputes, including land disputes, labor disputes and environmental disputes.

Labor disputes pertained as public dispute could disrupt public order and national stability, then the chances of complaints on violations of Labour Rights are to be submitted to the National Commission on Human Rightsbased on the contents of Article 90 of Law No. 39 of 1999 which reads in paragraph [1]: “Any person or group of people who have reasons to believe that the Rights have been violated can file reports and oral or written complaint to the National Commission on Human Rights." Then it is strengthened again in Chapter VIII of Article 101 of Law No. 39 of 1999 that the Institute of National Commission on Human Rights canaccommodate all the public reports onviolations of human rights.

\section{Labour Dispute Resolution Outside the \\ Court}

The settlement of the Industrial Relations disputes in PPHI Law allows the disputes settlementoutside the court.

a. Settlement through bipartite

Article 6 and Article 7 of PPHI Law suggest asettlement onlabor and employment disputes through consensus by bringing kinship principle amongthe workers and employers. If there is an agreement between the workers and employers or between the unions and employers, it can be stated in the agreement by both parties which is called as the collective agreement.

In the collective agreement or the deal must be signed by both parties as a shared document and a conciliationagreement.

b. Settlement through Mediation

The Government may appoint a Mediator assigned to conduct mediation or a conciliator to mediate in resolvingthe disputes between the workers and the employers. A mediatorappointedmustmeetthe requirements as they are stated in Article 9 of PPHI Law and the educational background is of at least Bachelor (S1). Within seven days after receiving the complaint from the workers, mediators have held the dispute case to be discussed in the meeting of the Mediation between the disputingparties

The appointment and accommodationof mediator are designated by the Minister of Labour. When it has reached an agreement of disputes settlement through the mediator, a collective agreement is made and signed by the disputing parties and the mediator, and then the agreement is registered in the Industrial Relations Court in the local District Court.

c. Settlement through Conciliation

Settlement through Conciliator is the Conciliation Officers whom the Minister of Labourappointed and laid off based on the recomedations from the union organization or the laborunion. All the requirements to become official conciliator are in Article 19 of PPHI Law. The most important task of a conciliator is to summon witnesses or the related parties within no later than seven days after receiving the settlement Conciliator letter.

Officials Conciliator may summon the disputing parties and make a collective 
agreement if the deal has been reached. The registration of the collective agreements is initiated by the conciliator and may be registered to the local District Court. Likewise, the execution will be carried out in the local District Court level.

d. Settlement through Arbitration

Law can resolve the dispute through arbitration that includes interest disputes and disputes between labor unions and employers within a company. To be determined as an arbitrator referring to Article 31, Paragraph [1] of PPHI Law, it reads:

1) Faithful and devoted to God Almighty;

2) Capable of taking legal action;

3) Indonesian citizen;

4) Minimum age of 45 (forty five) years;

5) The educational background of at least Bachelor (S1);

6) Being healthy based on a doctor's certificate;

7) Master the legislation in the field of employment proven by a certificate or an evidence of graduation that one haspassedexams and arbitration;

8) Having experience in the field of industrial relations at least for five years.

The appointment of the arbitrator is based on the Decree of the LabourMinister. The disputing parties can choose their preferred arbitrator as outlined by the Labour Minister. Arbitrators' sentence which raises doubt can be projected as a disavowal against the local District Court by listingauthentic reasons that cause such doubt. District Court in Article 38 of Law Dispute Resolution can make a sentenceregardingthe disavowal and a resistance can not be proposed again. If conciliation is achieved, then based onthe Article 44 of PPHI Law, an arbitrator must make a deed of conciliation signed by both parties in the presence of an arbitrator or Arbitrator Assembly.

The stipulation of the Peace Certificateis registered at the Court, and it can also be executed by the Court or taken as asentence, as usual. The agreement decision of Arbitrators is made triplicate and two duplicates are given to each party, and is registered at the Industrial Relations Court toward the decision that already has the law force and cannot be proposed anymore or the same dispute can not be projectedfurther to the Industrial Relations Court .

\section{Dispute Settlement through the Courts}

Before the release of the Industrial Relations Act Settlement onLaborDisputes, it is regulated in the Law Number 22 of 1957 through the P4D and P4P Judicial.

In anticipating the dispute settlememt and its distribution of Labor and Employment disputes, in line with the demands of the era, it is made and enactedon PPHI Law as a medium inIndustrial Relations judicial in addition to general courts.

In the Article 56 of PPHI Law, it is statedthatindustrial relations court has the authority to examine and decide:

a. In the first level is on rights disputes;

b. In the first and last is on the conflict of interests;

c. At the first level is on the dispute over termination of employment;

d. In the first and last of the dispute between trade unions / labor unionswithin one company.

The composition of the Industrial Relations Court in the District Court is:

a. Judge;

b. Ad Hoc Judge;

c. Deputy Registrar, and ; 
d. Substitute Registrar.

For the Court of Cassation at the Supreme Court consists of:

a. Supreme Court Judge;

b. Ad Hoc Judge at the Supreme Court; and

c. Registrar

The requirements to be appointed as an Ad Hoc judge at the Industrial Relations Court and Ad Hoc Judge at the Supreme Court shall include the followingrequirements:

a. Indonesian citizens;

b. Devoted to The God Almighty;

c. Loyal to Pancasila and the Constitution of the Republic of Indonesia Year 1945;

d. Minimum age of 30 (thirty) years;

e. Being healthy based on a doctor's certificate;

f. Authoritative, honest, fair, and wellbehave;

g. The educational background of at least Bachelor (S1), except for Ad Hoc Judge at the Supreme Court, the requirements of Law Degree, and ;

h. Having experience in the field of industrial relations at least for five years.

The nomination and the appointment of the Ad Hoc Judge in the Industrial Relations Court are based on the Presidential Decree on the Proposal of the Chairman of the Supreme Court of the Republic of Indonesia. Before taking the office, Ad Hoc Judge is obliged to take an oath or make a vowbased on his/her religion and belief as well as the respective Ad Hoc Judge may not be allowed to have concurrent positions as stated in Article 66 of Law No. 2 of 2004 concerning Industrial Relations Dispute Settlement.

The procedural law used to prosecute thedispute is Legal Civil Procedures in the General Court, specifically regulated by the PPHI Law while waiting for the Presidential
Decree on the Procedures for the Appointment of Ad Hoc Judge Employment. Before this law takes into effect in the community in the resolution of the employymenttermination, the KEP/MEN/150 of 2000 and Act No. 13 of 2003 on Manpower are still in used.

Based on the results of field research on industrial dispute resolution in Barito Kuala District, in managing the industrial relations disputes in Barito Kuala District data on patterns of the dispute as well as the efforts that are taken by employers and workers are extracted. Data regarding the settlement of industrial disputes in Barito Kuala are obtained from:

1. Industrial Relations Court of South Kalimantan Province;

2. Labor Department of South Kalimantan;

3. The Office of Manpower and Transmigration of Barito Kuala District;

4. Palm Oil Company of Foreign Capital Investment (FCI) and Domestic Investment Company (DCI) as many as one company;

5. Workers of Palm Oil Company working in Palm Oil Company of Foreign Capital Investment (FCI) and Domestic Investment Company (DCI) as many as one company.

Based on the information from the Industrial Relations Court of South Kalimantan Province, there is no dispute lawsuit of the palm oil plantation workers in Barito Kuala District. This shows that the efforts to resolve the dispute through litigation for industrial relation dispute of the workers in the palm oil plantations in Barito Kuala District is the last effort which hitherto has not been taken by the disputing parties to end the dispute .

Based on information from the Labor Department of South Kalimantan Province 
and Department of Social, Manpower and Transmigration of Barito Kuala District, there have beenindustrialdisputeshappens in Barito Kuala District for the workers in palm oilplantations. Until February 2015, data showed that there are about 15 (fifteen) disputes. They are within the scope of employment termination. Therefore, the employers and the workers chose to resolve the dispute through bipartite that is a negotiation among the disputing parties. This is settlement is taken because through a negotiation a familial atmosphere among the disputing parties might be raised so that the fair decision can be taken to the disputingparties, and it may also provide the efficiency of time, effort and cost .

The methods of the settlement negotiattion arecarried out through the following ways:

1. The disputing parties express their intention to settle the dispute through a written letter;

2. The determination of the time and place to be agreed for the negotiation;

3. The disputing parties meet each other; those are the employers and the workers which are accompanied by a union repressentative or the Department of Labor;

4. The negotiations start by expressing a dispute from the version of the employers and the workers';

5. The submission of a demandfrom the disputing parties through the negotiations;

6. The parties seek a win-win solution to take a decision for the disputesettlement;

7. Having achieved a solution and obtained the agreement, the disputingparties make a statement that they have ended the dispute and the parties in good faith will execute the contents of the disputesettlement;
8. A report of the dispute settlement through bipartite is submitted to the relevant agencies

Based on the information from the employers and workers, they are quite satisfied with this bipartite settle-ment method for settlement because through bipartite the justice could be met due to the consensus method and familial atmosphere. They assume that this familial atmosphere would be difficult to obtain through tripartite settlement especially through litigation. The workers and employers assume that a settlement through litigation will only bring perceived winners and losers so that the familial atmospeherethat is expectedcannot be seen. In addition the number of industrial disputes, they are still few and the palm oil plantation co-mpanies are relatively new with the averageof worker who works in fairly new period, it leads to the ways of se-ttlingthe disputes through bipartite which is more effective than a solution through tripartite manner or litigation

Basically, the bipartite settlement is a discussion forum held between workers and employers to exchange information and communicate so that things which have never beencommu-nicated between the parties and the subject of the dispute can be revealed in a bipartite forum. The existence of the bipartite institution is also regulated in the legislation that requires every employer who has 50 (fifty) or more workers in order to form a bipartite ins-titutions. This is because Bipartite expected as the frontline way to resolve the dispute before involving a third party for there is a view that only the disp-utingparties alone which are more aware of what they want and what data they have as well as the decision of what to expect from the settlement of the disputes, If an agreement is obtained, then 
the parties are obliged to sign an agreement which is called a collective agreement. This agreement is a peace treaty that will be kept and shall be executed by the parties. ${ }^{9}$

\section{CONCLUSION}

In relation to labor, sometimes there are nonconforming opinions of the parties to the agreement bound and they are caused by a variety of factors. The settlement of industrial relation disputescan be through stages: Bipartite; Mediation (Tripartite); Conciliation; Arbitration; and the Industrial Relations Court. Industrial Relations Court is the last effort for the disputing parties in industrial relations disputes that can not be resolved out of the court and isregulated in Law Number 2 of 2004 concerning Industrial Relations Court. Based on the Industrial Relations Court of South Kalimantan Province, there is no dispute lawsuit from either the industrialcompaniesor the workers from palm oilplantations that are located in Barito Kuala District. It shows that the efforts to resolve the dispute through litigation for industrial disputes in the palm oil plantations of Barito Kuala district is an effort that has never been done by the disputing companies.

\section{REFERENCES}

Anonim, Sumber: http://repository.usu. ac.id/bitstream/123456789/1522/1/ hkmadmkelelung.pdf, diaksestanggal 02 Oktober 2015.

Asyhadie, Zaeni, 2007, Hukum Kerja Hukum Ketenagakerjaan Bidang Hubungan Kerja, Jakarta: PT.Raja Grafindo Persada

9 Anonim, Sumber:http://repository.usu.ac.id/ bitstream/123456789/1522/1/hkmadm-kelelung. pdf, diaksestanggal 02 Oktober 2015.
Saprudin, 2013, Perkembangan Hukum Ketenagakerjaan di Indonesia, Yogjakarta: Aura Pustaka

Suhariwanto, Aspek Hukum Perlindungan Pekerja Dalam Mengantisipasi Pemogokan Kerja di Perusahaan . Unitas Vol. 9 No. 1, September 2000-Pebruari 2001

Soemardjono, Maria SW, 1989, Pedoman Pembuatan Usulan Penelitian, Yogyakarta: Fakultas Hukum Universitas Gadjah Mada Sutedi, Adrian, 2009, Hukum Perburuhan, Jakarta: Sinar Grafika

\section{Legislations}

Law No. 39 of 1999 on Human Rights

Law No. 21 of 2000 concerning Trade Union / Labour Union

Law No. 13 of 2003 on Labour

Law No. 2 of 2004 concerning Industrial Relations Dispute Settlement 